\title{
Pengembangan Modul Pembelajaran Tema Sistem Tata Surya Pada Siswa Kelas IV SDN Gedongombo 6 Kabupaten Tuban
}

\author{
Novialita Angga Wiratama1, Ina Agustin2, \\ novialita3@gmail.com11, inaagustin88@gmail.com² \\ PGSD, Universitas PGRI Ronggolawe Tuban
}

\begin{abstract}
The curriculum is always changing according to developments in science and technology. Curriculum design in education needs to be done to answer the needs of society and the challenges of changing times. The curriculum is a guide in achieving the objectives of implementing the teaching process. The SD learning process in implementing the 2013 curriculum is carried out in an integrated manner with the theme of linking between subjects so that it is expected to provide meaningful learning experiences for students. Teachers determine student success in learning so that superior human resources are created through the educational process. The module is a printed teaching material that teachers can use to present learning material. This study developed a module with the theme of the solar system, sub-theme Change in the Appearance of Celestial Objects in SDN Gedongombo 6, Semanding District, Tuban Regency in fourth grade students. The research used is the development of the learning module. The research procedure uses the Four-D model according to Thiagarajan. The data collection instrument for this module development research consists of an assessment instrument for the subject matter expert learning module, an assessment instrument for the linguist learning module, an assessment instrument for the learning module for media experts, student questionnaires, and a teacher questionnaire. From the results of module development that have been validated by experts, it is obtained data that the module still needs reforms. Learning data and information results in the effectiveness of learning. Evidence of the final test data using the module shows the achievement of KKM 75 by 21 students out of 25 students.
\end{abstract}

Keywords: curriculum, development, learning modules

\section{Abstrak}

The primary school learning process in implementing the 2013 curriculum is carried out in an integrated manner with the theme of linking between subjects so that it is expected to provide meaningful learning experiences for students. Teachers determine student success in learning so that superior human resources are created through the educational process. The module is a printed teaching material that teachers can use to present learning material. Therefore it is necessary to develop a learning module. The purpose of this development research was to determine the effectiveness of the module with the theme of the solar system, the sub-theme of the change in the appearance of celestial bodies in SDN Gedongombo 6, Kecamatan Semanding, Kabupaten Tuban in fourth grade students. The research procedure uses the Four-D model according to Thiagarajan. The data collection instrument for this module development research consists of an assessment instrument for the subject matter expert learning module, an assessment instrument for the linguist learning module, an assessment instrument for the learning module for media experts, and a student questionnaire. From the final results of module development that have been validated by experts, it is obtained data that the module in the content criteria has an SPV value of $85.94 \%$. The assessment of the accuracy of the narrative language was $90.83 \%$ after a revision was made according to the suggested validation results. Evidence of the final test data using the module shows the achievement of KKM 75 by 21 students out of 25 students.

Kata Kunci: kurikulum, pengembangan, modul pembelajaran

\section{PENDAHULUAN}

Penyempurnaan kurikulum pendidikan di Indonesia selalu dilakukan dalam kurun waktu tertentu. Pada tahun 2013 Kemendikbud Republik Indonesia melakukan penyempurnaan

Peer reviewed under responsibility of Universitas Nusantara PGRI Kediri.

(C) 2021 Universitas Nusantara PGRI Kediri, All right reserved, This is an open access article under the CC BY-SA license (https://creativecommons.org/licenses/by-sa/4.0/) 


\section{Efektor, Volume 8 Issue 1, 2021, Pages 69-78}

Novialita Angga Wiratama, Ina Agustin

kurikulum dari kurikulum tingkat satuan pendidikan (KTSP) menjadi kurikulum 2013 diterapkan pada semua jenjang pendidikan di Indonesia. Menurut Mulyasa (2013:213) Kurikulum memiliki sifat dinamis dengan segala pengembangan untuk mengikuti kemajuan ilmu pengetahuan dan teknologi. Dari waktu ke waktu perubahan kurikulum selalu terjadi. Kurikulum perlu dirancang untuk menjawab kebutuhan masyarakat dan tantangan perubahan zaman. Dalam pencapaian tujuan pendidikan kurikulum memegang peranan yang sangat vital. Kurikulum dijadikan acuan dan pedoman dalam mencapai tujuan pelaksanaan proses pengajaran. Hal ini sesuai dengan pendapat Arifin (2011:25) yang menyebutkan bahwa kurikulum dapat menentukan proses serta hasil sistem pendidikan. Kurikulum sebagai media dan pedoman dalam pelaksanaan pengajaran pada semua jenis dan semua tingkat pendidikan.

Pelaksanaan pembelajaran di tingkat sekolah dasar selanjutnya disebut SD dalam penerapan kurikulum 2013 dilaksanakan secara terpadu. Proses pembelajaran disajikan menggunakan tema untuk mengaitkan beberapa mata pelajaran. Diharapkan penerapan tersebut dapat memberikan kebermaknaan belajar bagi siswa. Pelaksanaan pembelajaran tematik di SD dilakukan dengan mengintegrasikan materi dari beberapa mata pelajaran ke dalam satu tema pembahasan tertentu. Pemaduan beberapa mata pelajaran dipersatukan oleh tema dalam kegiatan pembelajaran satu kali tatap muka. Subtema dari setiap tema saling berkaitan dengan yang lainnya. Penentuan tema dan subtema sebelum melakukan pembelajaran perlu dicermati. Sehingga subtema dapat dikembangkan dalam pembelajaran kontekstual dan aplikatif.

Pengembangan konsep pendidikan dalam kehidupan sehari-hari perlu dilakukan sejak siswa berada di tingkat SD. Menurut kamus besar Bahasa Indonesia makna dari pendidikan merupakan proses atau cara dari seorang pendidik. Peran seorang guru dalam proses pembelajaran akan lebih baik jika menguasai konsep dan materi pembelajaran. Menurut Hamalik (2017:53) menyebutkan bahwa banyak peran guru dalam pembelajaran, diantara guru sebagai pengajar, pembimbing, manajer maupun ilmuan yang dituntut untuk mampu menuangkan seluruh kemampuannya sehingga penerapan kurikulum dapat berhasil. Hal ini senada dengan pendapat Anshory, dkk (2018:36) yang memaparkan bahwa guru merupakan bagian penting dalam proses pendidikan guna terciptanya sumber daya manusia yang unggul. Proses pembelajaran yang ada di kelas tidak dapat dipisahkan dari kurikulum yang berlaku. Dari pendapat para pakar di atas dapat disimpulkan bahwa guru merupakan penentu keberhasil siswa dalam belajar sehingga tercipta insan manusia unggul melalui proses pendidikan. Dalam mencapai kompetensi, guru memerlukan bahan ajar yang dapat memfasilitasi siswa untuk belajar.

Menurut Lestari (2013:134) Bahan ajar yang dimaksudkan merupakan seperangkat materi pelajaran mengacu pada kurikulum yang berlaku digunakan dalam mencapai kompetensi yang telah ditentukan Modul pembelajaran merupakan salah satu bahan ajar cetak yang mempersyaratkan siswa untuk membaca. Hal tersebut sesuai dengan Akbar (2013:33) yang menjelaskan bahwa modul dapat dipelajari sendiri oleh siswa dan ditulis untuk satu satuan kompetensi mata pelajaran maupun paket bahan ajar. Modul yang dikembangkan dalam penelitian ini berisi satu unit materi pembelajaran dengan waktu belajar tertentu. Menurut Susilo dkk (2016:51) modul ialah bahan ajar cetak yang dirancang untuk dapat dipelajari secara mandiri oleh peserta didik. Hal senada juga dipaparkan oleh Daryanto (2013:31) yang 


\section{Efektor, Volume 8 Issue 1, 2021, Pages 69-78}

Novialita Angga Wiratama, Ina Agustin

menuturkan bahwa modul dikemas secara lengkap dan sistematis memuat seperangkat pengalaman belajar dan membantu penggunanya menguasai pembelajaran. Berinteraksi dengan modul dapat merubah pola belajar siswa. Belajar dengan membaca modul dapat membuat siswa terbiasa belajar mandiri tanpa harus ditemani oleh guru.

Penyusunan modul sebaiknya dilakukan dengan cermat. Menurut Pratiwi (2015: 122) modul harus memiliki tampilan yang menarik bagi pembacanya dan menggunakan bahasa sederhana dan komunikatif sehingga mudah dipahami oleh siswa. Modul terdiri dari beberapa bagian diantaranya judul dan petunjuk umum. Judul harus mencerminkan isi ataupun muatan modul tersebut. Sedangkan petunjuk umum berisi kata pengantar, daftar isi, peta konsep, glosarium yang memuat kata yang belum familiar bagi siswa disertai dengan artinya. Selain itu, modul juga berisi petunjuk penggunaan, kompetensi inti, kompetensi dasar, tujuan pembelajaran, uraian materi, LKPD dan evaluasi disertai dengan aminasi gambar dan pemilihan warna yang menarik bagi siswa. Menurut Majid (2013:176) menjelaskan bahwa modul merupakan program untuk pengajaran suatu pembahasan yang disusun secara sistematis,terarah dan oprasional untuk siswa. Modul salah satu bentuk bahan ajar berbasis cetakan yang dirancang untuk belajar secara mandiri oleh peserta pembelajaran, karena itu modul dilengkapi dengan petunjuk untuk belajar mandiri. Berdasarkan uraian tersebut disimpulkan bahwa modul merupakan bahan ajar cetak yang tersusun secara cermat disertai layout gambar yang menarik dan sistematis. Isi modul mencakup petunjuk penggunaan modul, isi materi, metode, lembar kerja siswa dan evaluasi yang dapat digunakan siswa untuk belajar secara mandiri. Modul pembelajaran memberikan peluang adanya penerapan pendekatan konstruktivistik kognitif dan pembentukan berpikir ilmiah pada siswa. Menurut Muldiyana dkk (2018:50) modul dikategorikan baik dan menarik apabila memenuhi karakteristik:

a) Self Intructional Modul memiliki ciri siswa mampu belajar secara mandiri, b) Self Contained. Materi pembelajaran dari satu unit kompetensi atau sub kompetensi yang dipelajari terdapat di dalam satu modul secara utuh. c).Stand Alone (berdiri sendiri) Modul yang dikembangkan tidak tergantung pada media lain. d)Adaptive. Modul mempunyai daya adaptif yang tinggi terhadap perkembangan ilmu dan teknologi. e) User Friendly. Modul hendaknya bersahabat dengan pembacanya. Setiap instruksi dan paparan informasi bersifat membantu dan bersahabat dengan pemakainya, termasuk kemudahan pemakai dalam merespon, mengakses sesuai dengan keinginan. Penggunaan bahasa yang sederhana, mudah dimengerti serta menggunakan istilah yang umum digunakan.

Belajar dilakukan manusia sepanjang hidupnya. Belajar merupakan proses seseorang dalam mendapatkan perubahan tingkah laku baru sebagai hasil pengalamannya sendiri dalam berinteraksi dengan lingkungannya (Slameto, 2012:2). Modul merupakan bahan ajar yang berperan sebagai teman belajar yang flesibel bagi siswa. Modul dapat digunakan siswa untuk belajar secara mandiri dimana saja dan kapan saja sesuai dengan keinginan siswa. Modul yang digunakan oleh siswa memiliki kemampuan untuk memberikan kesempatan belajar individu dan mandiri kepada siswa. Tujuan penelitian adalah mengembangkan modul pembelajaran tema sistem tata surya sub tema Perubahan Kenampakan Benda-benda Langit. Selain itu tujuan penelitian ini adalah untuk mengukur efektifitas modul pembelajaran di SDN Gedongombo 6 Kecamatan Semanding Kabupaten Tuban pada siswa kelas IV dengan jumlah 25 siswa. Secara 


\section{Efektor, Volume 8 Issue 1, 2021, Pages 69-78}

Novialita Angga Wiratama, Ina Agustin

terinci dapat diperolehnya modul pembelajaran yang mempunyai validitas meliputi validitas isi materi, validitas bahasa dan validitas media dari komponen animasi yang digunakan di dalam modul yang dikembangkan menurut ahli. Modul pembelajaran yang dikembangkan diharapkan dapat menambah sumber belajar bagi siswa untuk belajar mandiri terutama saat belajar jarak jauh ataupun daring pada masa pandemic covid 19 ini. Modul pembelajaran merupakan salah satu alternatif yang dapat digunakan untuk memberikan pengalaman belajar mandiri dan individu pada siswa. Mengingat selama ini, pada umumnya pembelajaran dilaksanakan dalam aktivitas belajar kelompok atau klasikal dan pembelajaran dilakukan dengan didampingi guru secara langsung di dalam kelas dan semenjak pandemic pandemi pembelajaran dilakukan secara daring ataupun jarak jauh.

\section{METODE PENELITIAN}

Jenis penelitian yang digunakan dalam penelitian pengembangan modul pembelajaran dengan tema sistem tata surya ini adalah Research and Development (R\&D). Penelitian ini merupakan suatu proses untuk mengembangkan produk baru berupa modul pembelajaran sebagai alat bantu siswa untuk belajar mandiri di masa pandemic covid19. Modul ini dikembangkan untuk siswa kelas IV SDN Gedongombo 6 Kabupaten Tuban. Prosedur penelitian ini menggunakan model Four-D menurut Thiagarajan (dalam Rochmad, 2012:61) meliputi empat tahapan yaitu define (pendefinisian), design (perancangan), develop (pengembangan), dan disseminate (penyebaran).

Instrumen pengumpulan data yang digunakan dalam penelitian pengembangan modul pembelajaran ini terdiri dari instrumen penilaian modul. Menurut Sugiyono (2015:334) analisis data proses mencari dan menyusun secara sistematis data yang diperoleh dari hasil wawancara, catatan lapangan, dan bahan-bahan lain, sehingga dapat mudah dipahami dan temuannya dapat diinformasikan kepada orang lain. Instrumen tes merupakan bagian penting dari modul pembelajaran, jadi tidak dibuat secara khusus. Data tentang validitasi isi pembelajaran, narasi isi pembelajaran, dan ilustrasi isi pembelajaran yang dijabarkan dalam instrumen penilaian modul pembelajaran menggunakan skala nilai empat. Butir-butir dalam instrumen skala nilai dikembangkan dengan memperhatikan indikator validitas isi pembelajaran, indikator validitas narasi isi pembelajaran, dan indikator validitas ilustrasi isi pembelajaran. Data validitas modul pembelajaran dalam penelitian ini dianalisis sesuai dengan jenis data dan tahapan pemerolehannya. Teknik analisis data yang digunakan dalam penelitian pengembangan modul ini berupa analisis butir, analisis rumpun dan analisis menyeluruh. Data validasi dari para validator berupa saran perbaikan atau coretan kesalahan dan skala nilai dari 1 sampai dengan 4. Analisis data jenis saran perbaikan dan coretan kesalahan, akan digunakan dasar melakukan revisi modul pembelajaran pada rumpun maupun secara menyeluruh yang salah.

$$
\begin{aligned}
& \text { SPV }=\frac{\text { Ksax }}{\mathrm{Pt}} \times 100 \% \\
& \mathrm{SPV}=\text { skor persentase validitas } \\
& \mathrm{Ksax}=\text { banyaknya skala nilai dipilih untuk aspek yang dinilai } \\
& \mathrm{Pt}=\text { penilaian tertinggi }
\end{aligned}
$$


Persentase akhir yang diperoleh dari validasi terentang dari 1 sampai dengan 100. Untuk kriteria kurang valid, maka modul pembelajaran harus direvisi. Untuk menentukan skala validitas aspek, maka skala nilai yang diberikan oleh para validator dari tiap butir jabaran rumpun dan keseluruhan dengan rumus validitas modul pembelajaran. Modul pembelajaran tidak layak pakai apabila memperoleh penilaian tidak valid.

Tabel 1 Kriteria Validitas Modul Pembelajaran

\begin{tabular}{cc}
\hline Rentang skala/skor & Kriteria \\
\hline $81-100$ & Sangat valid \\
$61-80$ & Valid \\
$41-60$ & Kurang valid (direvisi) \\
$1-40$ & Tidak valid \\
\hline
\end{tabular}

\section{HASIL DAN PEMBAHASAN}

\section{Penyajian Data}

Pada tahap reviuw konsultan ahli, dilibatkan 6 (enam) orang ahli, yakni masingmasing 2 (dua) orang ahli matapelajaran, ahli bahasa, dan ahli media para validator merupakan dosen di lingkungan Universitas PGRI Ronggolawe Tuban.

\section{Penilaian validasi isi pembelajaran melalui instrumen penilaian modul pembelajaran ahli matapelajaran disajikan dalam data sebagai berikut.}

Tabel 2 Data Validasi Isi Pembelajaran dari Ahli Matapelajaran

\begin{tabular}{|c|c|c|c|c|}
\hline \multirow[t]{2}{*}{ No. } & \multirow[t]{2}{*}{ ASPEK YANG DINILAI } & \multicolumn{2}{|l|}{ Nilai } & \multirow{2}{*}{$\begin{array}{l}\text { SPV } \\
(\%)\end{array}$} \\
\hline & & Ahli I & Ahli II & \\
\hline 1. & $\begin{array}{l}\text { Apakah indikator menjabarkan Komptensi Dasar } \\
\text { mendeskripsikan perubahan kenampakan benda langit dan } \\
\text { posisi bulan? }\end{array}$ & 4 & 3 & 87,5 \\
\hline 2. & $\begin{array}{l}\text { Kejelasan pengembangan indikator menjadi tujuan } \\
\text { pembelajaran }\end{array}$ & 3 & 4 & 87,5 \\
\hline 3. & $\begin{array}{l}\text { Apakah pokok-pokok isi pembelajaran menjabarkan } \\
\text { indikator? }\end{array}$ & 4 & 3 & 87,5 \\
\hline 4. & $\begin{array}{l}\text { Kesesuaian lembar kerja pebelajar dengan tugas/soal } \\
\text { latihan pada isi dan kegiatan pembelajaran }\end{array}$ & 3 & 3 & 75 \\
\hline 5. & $\begin{array}{l}\text { Kejelasan kunci jawaban tugas/soal latihan pada lembar } \\
\text { kerja pebelajar }\end{array}$ & 4 & 4 & 100 \\
\hline 6. & $\begin{array}{l}\text { Tingkat kebenaran kunci jawaban penilaian terhadap } \\
\text { tugas/soal latihan }\end{array}$ & 4 & 4 & 100 \\
\hline 7. & Kesesuaian butir-butir soal dengan tujuan pembelajaran & 3 & 3 & 75 \\
\hline 8. & $\begin{array}{l}\text { Tingkat kebenaran kunci jawaban penilaian terhadap soal } \\
\text { penilaian }\end{array}$ & 3 & 4 & 87,5 \\
\hline & JUMLAH SKOR PERSENTASE & 28 & 27 & 700 \\
\hline
\end{tabular}

Data dari hasil validasi isi mata pelajaran terhadap 2 orang ahli matapelajaran diperoleh informasi sebagai berikut. bahwa saran dan catatan kesalahan sebagai berikut. Perlu ada perbaikan dalam pengembangan indicator menjadi tujuan pembelajaran. Kesalahan isi pembelajaran pada bagian materi halaman 11 yang perlu diperbaiki. Kesalahan isi pembelajaran pada bagian istilah gaya gravitasi. Pemberian keterangan gambar dan keaslian ilustrasi gambar. 
Efektor, Volume 8 Issue 1, 2021, Pages 69-78

Novialita Angga Wiratama, Ina Agustin

\section{Data validasi ahli bahasa penilaian modul pembelajaran, dapat ditabulasikan dalam tabel di bawah ini.}

Perolehan skor validasi dari ahli bahasa adalah sebagai berikut. Perlu perubahan tata letak kata sambung, dan penulisan kata depan. Perbaikan penulisan kata, dan pemilihan penggunan kata agar lebih mudah dipahami siswa.

Tabel 3 Data Validasi Ahli Bahasa

\begin{tabular}{|c|c|c|c|c|}
\hline \multirow[t]{2}{*}{ No. } & \multirow[t]{2}{*}{ ASPEK YANG DINILAI } & \multicolumn{2}{|l|}{ Nilai } & \multirow{2}{*}{$\begin{array}{l}\text { SPV } \\
(\%)\end{array}$} \\
\hline & & Ahli I & Ahli II & \\
\hline 1. & $\begin{array}{l}\text { Apakah kata-kata yang digunakan pada narasi memenuhi } \\
\text { aturan kebakuan kata Bahasa Indonesia? }\end{array}$ & 3 & 3 & 75 \\
\hline 2. & $\begin{array}{l}\text { Kalimat lisan yang dituliskan, apakah memenuhi kebakuan } \\
\text { kalimat Bahasa Indonesia? }\end{array}$ & 3 & 4 & 87,5 \\
\hline 3. & $\begin{array}{l}\text { Bagaimanakah tingkat kejelasan konsep yang } \\
\text { dinarasikan? }\end{array}$ & 3 & 3 & 75 \\
\hline 4. & Apakah tanda baca pada narasi digunakan secara benar? & 3 & 3 & 75 \\
\hline 5. & $\begin{array}{l}\text { Pada Bagian 1: Petunjuk Guru. Apakah narasi sesuai } \\
\text { dengan karakteristik guru? }\end{array}$ & 4 & 4 & 100 \\
\hline 6. & $\begin{array}{l}\text { Pada Bagian 1: Petunjuk Pembelajar. Apakah narasi } \\
\text { sesuai dengan karakteristik pembelajar (guru)? }\end{array}$ & 4 & 4 & 100 \\
\hline 7. & $\begin{array}{l}\text { Pada bagian } 2 \text { : Petunjuk Kegiatan siswa. Apakah narasi } \\
\text { sesuai dengan karakteristik siswa? }\end{array}$ & 4 & 4 & 100 \\
\hline 8. & $\begin{array}{l}\text { Pada bagian } 2 \text { : Petunjuk Kegiatan Pebelajar. } \\
\text { Bagaimanakah tingkat kejelasan narasi bagi siswa? }\end{array}$ & 4 & 4 & 100 \\
\hline 9. & $\begin{array}{l}\text { Pada bagian 2: Petunjuk Kegiatan Siswa. Bagaimanakah } \\
\text { tingkat kejelasan narasi tugas/latihan/ kegiatan bagi } \\
\text { siswa? }\end{array}$ & 4 & 4 & 100 \\
\hline 10. & $\begin{array}{l}\text { Pada bagian } 3 \text { :Lembar Kerja Siswa. Apakah narasi sesuai } \\
\text { dengan karakteristik siswa? }\end{array}$ & 3 & 4 & 87,5 \\
\hline 11. & $\begin{array}{l}\text { Pada bagian } 3 \text { :Lembar Kerja Siswa. Bagaimanakah } \\
\text { tingkat kejelasan narasi bagi siswa)? }\end{array}$ & 4 & 3 & 87,5 \\
\hline 12. & $\begin{array}{l}\text { Pada bagian } 4 \text { : Lembar Penilaian. Apakah narasi sesuai } \\
\text { dengan karakteristik siswa? }\end{array}$ & 3 & 4 & 87,5 \\
\hline 13. & $\begin{array}{l}\text { Pada bagian 4: Lembar Penilaian. Bagaimanakah tingkat } \\
\text { kejelasan narasi bagi siswa? }\end{array}$ & 4 & 4 & 100 \\
\hline 14. & $\begin{array}{l}\text { Pada bagian 5: Lembar Jawaban Penilaian. Apakah narasi } \\
\text { sesuai dengan karakteristik siswa? }\end{array}$ & 4 & 3 & 87,5 \\
\hline 15. & $\begin{array}{l}\text { Pada bagian 5: Lembar Jawaban Penilaian. } \\
\text { Bagaimanakah tingkat kejelasan narasi bagi siswa? }\end{array}$ & 4 & 3 & 87,5 \\
\hline & JUMLAH SKOR PERSENTASE & 55 & 54 & 1362,5 \\
\hline
\end{tabular}

Data validasi ahli media pembelajaran dapat ditabulasikan dalam tabel di bawah ini.

Tabel 4 Data Validasi dari Ahli Media Pembelajaran

\begin{tabular}{|c|c|c|c|c|c|c|}
\hline \multirow[t]{2}{*}{ No. } & \multicolumn{2}{|l|}{ ASPEK YANG DINILAI } & & \multicolumn{2}{|l|}{ Nilai } & \multirow{2}{*}{$\begin{array}{l}\text { SPV } \\
(\%)\end{array}$} \\
\hline & & & & Ahli I & Ahli II & \\
\hline 1. & $\begin{array}{l}\text { Kejelasan narasi dan ilustrasi } \\
\text { pembelajaran tentang bintang }\end{array}$ & (gambar) & isi & 4 & 3 & 87,5 \\
\hline 2. & $\begin{array}{l}\text { Kejelasan narasi dan ilustrasi } \\
\text { pembelajaran tentang matahari }\end{array}$ & (gambar) & isi & 4 & 4 & 100 \\
\hline 3. & Kejelasan narasi dan ilustrasi & (gambar) & isi & 3 & 3 & 75 \\
\hline
\end{tabular}


Efektor, Volume 8 Issue 1, 2021, Pages 69-78

Novialita Angga Wiratama, Ina Agustin

\begin{tabular}{|c|c|c|c|c|}
\hline & pembelajaran tentang bulan & & & \\
\hline 4. & Kelengkapan cover modul pembelajaran & 4 & 4 & 100 \\
\hline 5. & Kejelasan dan kemenarikan modul pembelajarn & 3 & 3 & 75 \\
\hline \multirow[t]{2}{*}{6.} & $\begin{array}{l}\text { Kesesuaian ilustrasi isi pembelajaran dengan } \\
\text { kompetensi dasar }\end{array}$ & 4 & 4 & 100 \\
\hline & JUMLAH SKOR PERSENTASE & 30 & 29 & 662,5 \\
\hline
\end{tabular}

Dari data di atas diperoleh informasi mengenai saran dan catatan kesalahan ilustrasi isi pembelajaran dari ahli media adalah terkait dengan kemenarikan pada cover dan ilustrasi cover harus mewakili cerminan isi. llustrasi yang disertakan pada narasi dimaksudkan untuk memperjelas konsep materi yang disampaikan. Ahli matapelajaran menganjurkan diberikan sedikit narasi dan penomoran pada ilustrasi gambar. Data pendukung efektivitas modul pembelajaran berupa hasil tes awal dan tes akhir pebelajar yang menjadi subyek penelitian ini seperti ditabulasikan berikut. Data sudah diklasifikasikan dalam empat kelas interval untuk keperluan tabulasi ini.

Tabel 5 Data Tes Awal dan Tes Akhir Pemanfaatan Modul Pembelajaran

\begin{tabular}{cccc}
\hline Kelas Interval & Tes Awal & Tes Akhir & Keterangan \\
\hline $75-100$ & - & 21 & \\
$50-74$ & 5 & 2 & \\
$25-49$ & 17 & 2 & \\
$1-24$ & 3 & - & \\
\hline
\end{tabular}

Dari data di atas diperoleh informasi bahawa siswa kelas IV SDN Gedongombo 6 berjulah 25 melakukan tes awal dan akhir dalam penggunaan modul pembelajaran bertema system tata surya. Pada penggunaan modul pembelajaran dilakukann tes awal diperoleh data nilai sebagai berikut. 5 siswa mendapatkannilai pada interval 50-74. 17 siswa mendapat nilai pada rentang kelas interval 25 hingga 49, sedangkan 3 siswa mendapatkan nilai pada rentang 1 hingga 24. Dari hasil kegiatan tes akhir diperoleh data bahwa 21 siswa mendapatkan nilai pada kelas interval 75 sampai 100 . sedangkan 2 siswa mendapatkan nilai pada kelas interval 50 hingga 74, sedangkan 2 siswa memperoleh nilai pada interval kelas 25-49. Bukti data tes akhir penggunaan modul menunjukan tercapainya KKM 75 oleh 21 orang siswa dari 25 orang siswa.

\section{Analisis Data}

Pada tahap reviu konsultan ahli, data dianalisis sesuai dengan rumpun materi pembelajaran, penggunaan bahasa dalam narasi isi pembelajaran, dan ilustrasi isi pembelajaran. Data yang dianalisis adalah data yang sudah disajikan pada tabel berikut ini. Penetapan validitas dari masing-masing butir yang ada pada setiap rumpun, dan secara keseluruhan didasarkan pada Kriteria Validitas Modul Pembelajaran.

Tabel 6 ketetapan Validitas Isi Modul Pembelajaran

\begin{tabular}{|c|c|c|c|}
\hline No. & ASPEK PENILAIAN & $\begin{array}{l}\text { SPV } \\
(\%)\end{array}$ & $\begin{array}{l}\text { Ketetapan } \\
\text { Validitas }\end{array}$ \\
\hline 1. & $\begin{array}{l}\text { Apakah indikator menjabarkan Komptensi Dasar } \\
\text { mendeskripsikan perubahan kenampakan benda langit dan } \\
\text { posisi bulan? }\end{array}$ & 87,5 & $\begin{array}{l}\text { Sangat } \\
\text { Valid }\end{array}$ \\
\hline 2. & Kejelasan pengembangan indikator menjadi tujuan & 87,5 & Sangat \\
\hline
\end{tabular}


Efektor, Volume 8 Issue 1, 2021, Pages 69-78

Novialita Angga Wiratama, Ina Agustin

\begin{tabular}{|c|c|c|c|}
\hline & pembelajaran & & Valid \\
\hline 3. & $\begin{array}{l}\text { Apakah pokok-pokok isi pembelajaran menjabarkan } \\
\text { indikator? }\end{array}$ & 87,5 & $\begin{array}{l}\text { Sangat } \\
\text { Valid }\end{array}$ \\
\hline 4. & $\begin{array}{l}\text { Kesesuaian lembar kerja pebelajar dengan tugas/soal } \\
\text { latihan pada isi dan kegiatan pembelajaran }\end{array}$ & 75 & Valid \\
\hline 5. & $\begin{array}{l}\text { Kejelasan kunci jawaban tugas/soal latihan pada lembar } \\
\text { kerja siswa }\end{array}$ & 100 & $\begin{array}{l}\text { Sangat } \\
\text { Valid }\end{array}$ \\
\hline 6. & $\begin{array}{l}\text { Tingkat kebenaran kunci jawaban penilaian terhadap } \\
\text { tugas/soal latihan }\end{array}$ & 87,5 & $\begin{array}{l}\text { Sangat } \\
\text { Valid }\end{array}$ \\
\hline 7. & Kesesuaian butir-butir soal dengan tujuan pembelajaran & 75 & Valid \\
\hline \multirow[t]{2}{*}{8.} & $\begin{array}{l}\text { Tingkat kebenaran kunci jawaban penilaian terhadap soal } \\
\text { penilaian }\end{array}$ & 87,5 & $\begin{array}{l}\text { Sangat } \\
\text { Valid }\end{array}$ \\
\hline & SKOR PERSENTASE VALIDASI KESELURUHAN & 85,94 & $\begin{array}{l}\text { Sangat } \\
\text { Valid }\end{array}$ \\
\hline
\end{tabular}

Paparan informasi data pada tabel di atas sebagai berikut. Hasil validasi ahli materi pembelajaran menunjukan bahwa isi modul pembelajaran tidak ada yang perlu direvisi. Sementara ketetapan validasi narasi bahasa tersaji dalam tabel berikut ini.

Tabel 7 Ketetapan Validitas Bahasa Narasi Isi Modul Pembelajaran

\begin{tabular}{|c|c|c|c|}
\hline No. & ASPEK PENILAIAN & $\begin{array}{l}\text { SPV } \\
(\%)\end{array}$ & $\begin{array}{l}\text { Ketetapan } \\
\text { Validitas }\end{array}$ \\
\hline 1. & $\begin{array}{l}\text { Apakah kata-kata yang digunakan pada narasi memenuhi aturan } \\
\text { kebakuan kata Bahasa Indonesia? }\end{array}$ & 75 & Valid \\
\hline 2. & $\begin{array}{l}\text { Kalimat lisan yang dituliskan, apakah memenuhi kebakuan kalimat } \\
\text { Bahasa Indonesia? }\end{array}$ & 87,5 & Sangat Valid \\
\hline 3. & Bagaimanakah tingkat kejelasan konsep yang dinarasikan? & 75 & Valid \\
\hline 4. & Apakah tanda baca pada narasi digunakan secara benar? & 75 & Valid \\
\hline 5. & Pada Bagian 1: Apakah narasi sesuai dengan karakteristik guru? & 100 & Sangat Valid \\
\hline 6. & Pada Bagian 1: Apakah narasi sesuai dengan karakteristik guru? & 100 & Sangat Valid \\
\hline 7. & $\begin{array}{l}\text { Pada bagian } 2 \text { : Petunjuk Kegiatan. Apakah narasi sesuai dengan } \\
\text { karakteristik siswa? }\end{array}$ & 100 & Sangat Valid \\
\hline 8. & $\begin{array}{l}\text { Pada bagian } 2 \text { : Petunjuk Kegiatan. Bagaimanakah tingkat } \\
\text { kejelasan narasi bagi siswa? }\end{array}$ & 100 & Sangat Valid \\
\hline 9. & $\begin{array}{l}\text { Pada bagian 2: Petunjuk Kegiatan Siswa. Bagaimanakah tingkat } \\
\text { kejelasan narasi tugas/latihan/ kegiatan bagi siswa? }\end{array}$ & 100 & Sangat Valid \\
\hline 10. & $\begin{array}{l}\text { Pada bagian } 3 \text { :Lembar Kerja Siswa. Apakah narasi sesuai dengan } \\
\text { karakteristik siswa? }\end{array}$ & 87,5 & Sangat Valid \\
\hline 11. & $\begin{array}{l}\text { Pada bagian } 3 \text { :Lembar Kerja Siswa. Bagaimanakah tingkat } \\
\text { kejelasan narasi bagi siswa? }\end{array}$ & 87,5 & Sangat Valid \\
\hline 12. & $\begin{array}{l}\text { Pada bagian } 4 \text { : Lembar Penilaian. Apakah narasi sesuai dengan } \\
\text { karakteristik siswa? }\end{array}$ & 87,5 & Sangat Valid \\
\hline 13. & $\begin{array}{l}\text { Pada bagian 4: Lembar Penilaian. Bagaimanakah tingkat } \\
\text { kejelasan narasi bagi siswa? }\end{array}$ & 100 & Sangat Valid \\
\hline 14. & $\begin{array}{l}\text { Pada bagian 5: Lembar Jawaban Penilaian. Apakah narasi sesuai } \\
\text { dengan karakteristik siswa? }\end{array}$ & 87,5 & Sangat Valid \\
\hline 15. & $\begin{array}{l}\text { Pada bagian 5: Lembar Jawaban Penilaian. Bagaimanakah tingkat } \\
\text { kejelasan narasi bagi siswa? }\end{array}$ & 87,5 & Sangat Valid \\
\hline
\end{tabular}




\section{Efektor, Volume 8 Issue 1, 2021, Pages 69-78}

Novialita Angga Wiratama, Ina Agustin

Tabel di atas menunjukan bahwa untuk butir-butir validasi bahasa narasi isi modul pembelajaran dari validator tidak ada yang perlu direvisi.Ketepatan hasil validasi menunjukkan valid dan sangat valid. Paparan data dari siswa SDN Gedongombo 6 Kabupaten Tuban diperoleh data sebagai berikut.

\section{SIMPULAN}

Produk akhir dalam penelitian berupa modul pembelajaran. Modul tervalidasi sesuai dengan spesifikasi, isi pembelajaran, tervalidasi bahasa narasi isi pembelajaran, dan tervalidasi ilustrasi media pembelajaran dengan tema sistem tata surya sub tema Perubahan Kenampakan Benda-benda Langit. Isi pembelajaran berupa konsep teoritis tidak membutuhkan praktik untuk menguasainya. Penguasaan konsep teoritis dalam modul dilakukan siswa melalui membaca. Membaca sebagai aktivitas utama modul pembelajaran sangat cocok untuk menyajikan topik perubahan kenampakan benda-benda langit kepada siswa. Ahli matapelajaran setuju dengan pengorganisasian isi pembelajaran yang memperhatikan perkembangan kognitif siswa.

Modul pembelajaran ditandai dengan narasi dan ilustrasi pembelajaran yang komunikatif, karena individu belajar dengan menggunakan ide-ide yang disajikan dalam paket pembelajaran. Narasi bahasa pada isi modul ini menggunakan bahasa komunikatif, menurut ahli bahasa, akibatnya kurang memperhatikan kebakuan bahasa. Penilaian ahli bahasa yang menyarankan perubahan kata, kalimat, dan tanda baca yang baku, diakomodasi tanpa mengurangi kekomunikatifan bahasa narasi isi pembelajaran. Ilustrasi yang disertakan pada narasi dimaksudkan untuk memperjelas konsep yang disampaikan. Validasi uji coba lapangan menunjukkan bahwa isi pembelajaran yang disajikan melalui narasi dan ilustrasi yang komunikatif menghasilkan. Wena (2010:6) mengemukakan bahwa efektivitas pembelajaran menggunakan modul diukur dari tingkat pencapaian siswa. Terdapat 4 indikator untuk mendeskripsikan yaitu (1) kecermatan penguasaan perilaku yang dipelajari, (2) kecepatan unjuk kerja, (3) tingkat alih belajar, dan (4) tingkat retensi. Data dan informasi pembelajaran menghasilkan efektivitas pembelajaran. Bukti data tes akhir juga menunjukan tercapainya KKM 75 oleh 21 orang siswa dari 25 orang siswa.

Modul pembelajaran yang dikembangkan secara empiris telah tervalidasi pada tahap reviu validator ahli maupun uji coba lapangan. Diseminasi modul pembelajaran yang telah dikembangkan dengan tema Sistem tata surya dilakukan dengan mensosialisasikan efektivitas pemanfaatan modul pembelajaran kepada siswa. Memberikan pelatihan pemanfaatan modul pembelajaran kepada siswa. Mensosialisasikan pemanfaatan modul pembelajaran kepada siswa, dengan harapan tidak terjadi keterkejutan saat modul pembelajaran dimanfaatkan. Memberikan pendampingan kepada siswa saat modul pembelajaran dimanfaatkan pertama kali. Mengadakan penilaian sumatif pemanfaatan modul pembelajaran. Mendiseminasikan modul pembelajaran di SD lain yang berkeinginan memanfaatkan modul pembelajaran.

Pengembangan modul pembelajaran lebih lanjut dapat dilakukan kegiatan-kegiatan berikut. Mengurangi penggunaan warna, untuk mengurangi biaya tinggi pengembangan modul pembelajaran. Mengembangkan modul pembelajaran penunjang perbaikan dan pengayaan selain modul pembelajaran bagian. Setiap modul pembelajaran, sebaiknya mencantumkan KI dan KD. Mengadakan revisi secara rutin terhadap modul pembelajaran, agar diperoleh modul pembelajaran yang semakin efisien dan efektif pemanfaatannya. Mengembangkan modul pembelajaran untuk topik pembelajaran yang lain di kelas yang berbeda. 


\section{Efektor, Volume 8 Issue 1, 2021, Pages 69-78}

Novialita Angga Wiratama, Ina Agustin

\section{DAFTAR RUJUKAN}

Akbar, Sa'dun. 2013. Instrumen Perangkat Pembelajaran. Bandung: PT Remaja Rosda Karya.

Anshory, Ichsan., dkk. 2018. Pembelajaran Tematik Integratif Pada Kurikulum 2013 Di Kelas Rendah Sd Muhammadiyah 07 Wajak. Jurnal Inovasi Pembelajaran, Vol.4, No.1

Arifin, Zainal. 2011. Konsep \& Model Pengembangan Kurikulum. Bandung: Remaja Rosdakarya.

Daryanto. 2013. Menyusun Modul Bahan Ajar untuk Persiapan Guru dalam Mengajar. Yogyakarta: Gava Media.

Hamalik, O. (2017). Dasar-dasar Pengembangan Kurikulum. Bandung: PT Remaja Rosdakarya.

Kamus Besar Bahasa Indonesia. 2013. (online).(http://www.kkbi.web.id. Diakses 20 Mei 2021).

Lestari, Ika. 2013. Pengembangan Bahan Ajar Berbasis Kompetensi (sesuai dengan kurikulum tingkat satuan pendidikan). Padang: Akademi Permata.

Majid, Abdul. 2013. Perencanaan Pembelajaran. Bandung: PT Remaja Rosdakarya.

Muldiyana, dkk. 2018. Pengembangan Modul Cetak Pada Mata Pelajaran Produktif Teknik Komputer Dan Jaringan Di SMK Negeri 2 Watampone. Jurnal Teknologi Pendidikan Vol. 20, No. 1, 43-59.

Mulyasa. E. 2013. Pengembangan dan Implementasi Kurikulum 2013. Bandung: PT Remaja Rosdakarya.

Pratiwi,P.H. 2015. Perencanaan Pembelajaran Sosiologi. Yogyakarta: UNY Press.

Rochmad, 2012. Desain Model Pengembangan Perangkat Pembelajaran Matematika. Jurnal Kreano. Volume 3 Nomor 1, 59-72.

Septyenthi, Sica, dkk. 2014. Pengembangan Modul Pembelajaran IPA Berbasis Entrepreneurship di SMK Negeri 2 Kota Jambi. Edu-Sains Volume 3 No. 2,21-35

Sugiyono, 2015.Metode Penelitian Kuantitatif Kualitatif dan R\&D. Bandung: Penerbit Alfabeta.

Slameto. 2012. Belajar\&Faktor-Faktor yang Mempengaruhi. Jakarta: Rineka Cipta.

Susilo, Agus, dkk. 2016. Pengembangan Modul Berbasis Pembelajaran Saintifik Untuk Peningkatan Kemampuan Mencipta Siswa Dalam Proses Pembelajaran Akuntansi Siswa Kelas Xii Sma N I Slogohimo 201. Jurnal Pendidikan IImu Sosial, Vol 26, No.1, 50-56.

Wena, Made. 2010. Strategi Pembelajaran Inovatif Kontemporer: Satu Tinjauan Konseptual Operasional.Jakarta : Bumi Aksara. 